\title{
One-month Progress of COVID-19 Cases in East Kalimantan, Indonesia
}

\author{
Swandari Paramita, Anton Rahmadi*, Ronny Isnuwardana, Rudy Agung Nugroho \\ Center of Excellence for Tropical Studies, Mulawarman University, Samarinda, East Kalimantan, Indonesia
}

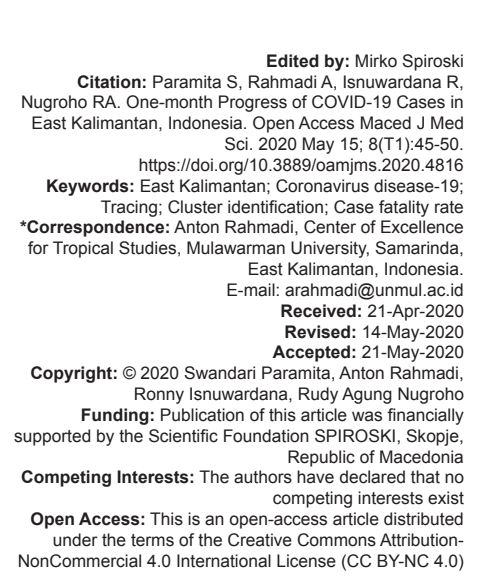

Introduction

Coronavirus disease 2019 (COVID-19), a disease which causes by the severe acute respiratory syndrome coronavirus 2 (SARS-CoV-2) started as reported cases of respiratory illnesses from Wuhan, China by the end of 2019 and eventually spread all over the world in the following months, which forced World Health Organization (WHO) to declare it as pandemic by March 11, 2020 [1], [2]. To curb the spread of SARSCoV-2, many countries implemented several measures such as limiting to closing border movements, community-wide isolation, and preventing the gathering of people [3], [4], [5].

Indonesia officially confirmed its first COVID-19 case on March 02, 2020. In the announcement by the President of the Republic of Indonesia, the first cluster was identified as a dance class [6]. In this cluster, 13 people were later positively identified as COVID19 cases [7]. Three major activities which occurred between February 26, 2020 and February 28, 2020 were identified as clusters of COVID-19 transmission: The Seminar Sinode Bogor, Seminar Anti Riba Bogor, and Seminar Kerohanian Lembang [8]. Participants in these events came from all regions of Indonesia, including East Kalimantan. On March 18-20, 2020, East Kalimantan confirmed nine COVID-19 patients, the majority of them coming from the two main clusters: The Seminar Sinode Bogor, Indonesia and Seminar Anti Riba Bogor, Indonesia. There was a confirmed positive patient from another cluster, the General Election Commission meeting in Jakarta [9].

East Kalimantan has been selected as the location for the new capital of the Republic of Indonesia [10]. Consequently, the flow of people in and out of East Kalimantan has increased rapidly. Despite this, health-care facilities in East Kalimantan are still limited compared to similar facilities on the island of Java. For this reason, the spread of COVID-19 needs special attention, given the nature of rapid transmission and the need for significant intensive care unit facilities [11]. Management of infectious diseases such as COVID-19 requires special arrangements such as negative pressure isolation rooms, personal protective equipment with a level three biosafety standard, and ventilators to help critical patients [12]. Therefore, the provincial government set several measures in place to flatten the curve of the COVID-19 infection rate and to prevent health services from being overloaded.

Recording the events surrounding the COVID-19 pandemic is needed as a future learning 
effort for similar outbreaks that might occur in East Kalimantan. The purpose of the present study was to descriptively convey information about COVID-19 cases in East Kalimantan during the period from March 18, 2020, to April 18, 2020.

\section{Materials and Methods}

\section{Data collection}

Timeline information on the COVID-19 cases in East Kalimantan was tracked from broadcasts and announcements from the East Kalimantan Provincial Health Office [13], Samarinda City Health Office [14], and Balikpapan City Health Office [15] news channels based on official announcements and reportage, interviews, and communication with field workers at health offices in East Kalimantan, Hospitals, and Emergency Reporting Task Force 112.

\section{Data processing}

Official data collected from the Provincial Health Office, Samarinda City Health Office, and Balikpapan City Health Office were collated in a database and analyzed using Microsoft Office Excel software.

\section{Statistical analysis}

Statistical analysis was performed by Microsoft Office Excel 365 (Microsoft, Redmond, Washington, USA).

\section{Ethics statement}

The laboratory and diagnostic procedures of this study were approved by the Health Research Ethics Committee of the Faculty of Medicine, Mulawarman University, Samarinda, East Kalimantan, Indonesia (Jl. Kerayan Kampus Gunung Kelua, Samarinda, East Kalimantan, Indonesia).

\section{Results and Discussion}

\section{Progress of COVID-19 cases}

COVID-19 cases were first reported in Jakarta, Indonesia since March 02, 2020, and following that, the first case in East Kalimantan province was detected on March 18, 2020. The timeline of COVID-19 progression in East Kalimantan Province can be seen in Table 1.

\section{rapid tests}

Tracing and Isolation before the use of

The WHO has established procedures for handling infectious diseases with four main steps: Isolate, test, treat, and trace [16]. The implementation of this handling procedure has varied by country. For example, South Korea initiated a large scale use of rapid tests [17], China implemented strict lockdown procedures in affected provinces [18], India has used force to curb dissidents in lockdown [19], and Indonesia has established large-scale social restrictions [20].

In Indonesia, there have been differences between regions in the way that people under observation (PUO) and patients under investigation (PUI) have been determined [21]. East Kalimantan, for example, with a population of about 3.7 million, has more PUO than other more populated provinces [22]. The determination of PUO, in general, is based on a history of trips to an area with the local transmission or overseas travel [23]. In East Kalimantan, the community's compliance in reporting themselves to the hotline number 112 or 119 in Samarinda and Balikpapan was good, and the performance of the hotline team was also satisfactory. The mean daily tracing performance from March 20, 2020, to April 18, 2020, was one positive confirmed for every 14.3 PUO and one positive confirmed for every 6.9 PUls. In addition, $48 \%$ of the PUls were confirmed negative.

The Samarinda and Balikpapan fast response teams quickly disseminated information on the initially identified clusters such as the Seminar Sinode Bogor, Seminar Anti Riba Bogor, General Election Commission meetings, and other trips or meetings in areas with local transmission. This information was widely disseminated through social media channels in one or several posts which were easy to read and understand [24]. The return of participants from ljtima Gowa was considered as a very challenging tracing activity, due to the sheer number of people and their locations.

The performance of the tracing can be calculated based on daily published data by the East Kalimantan Health Office. For example, on March 19, 2020, the first publicly available data, there were 208 PUOs, 39 PUls, three positives and 11 negatives [13]. This means COVID-19 positive individuals as a percentage of total PUO and PUI at that time were $1.4 \%$ and $7.7 \%$, respectively. The highest percentage of COVID-19 positive of PUO and PUI occurred on March 28, 2020, with $21.0 \%$ and $0.7 \%$, respectively. On a monthly mean, the percentage of COVID-19 positive of PUO and PUI was $14.4 \%$ and $0.7 \%$, respectively.

Before the COVID-19 rapid test kit was received by the East Kalimantan Health Office, the procedure for determining PUI status was based on the Pedoman Pencegahan dan Pengendalian COVID-19 which had been revised 3 times by the Ministry of Health of the Republic of Indonesia [11]. PUI was determined 
Table 1: COVID-19 timeline in East Kalimantan, Indonesia

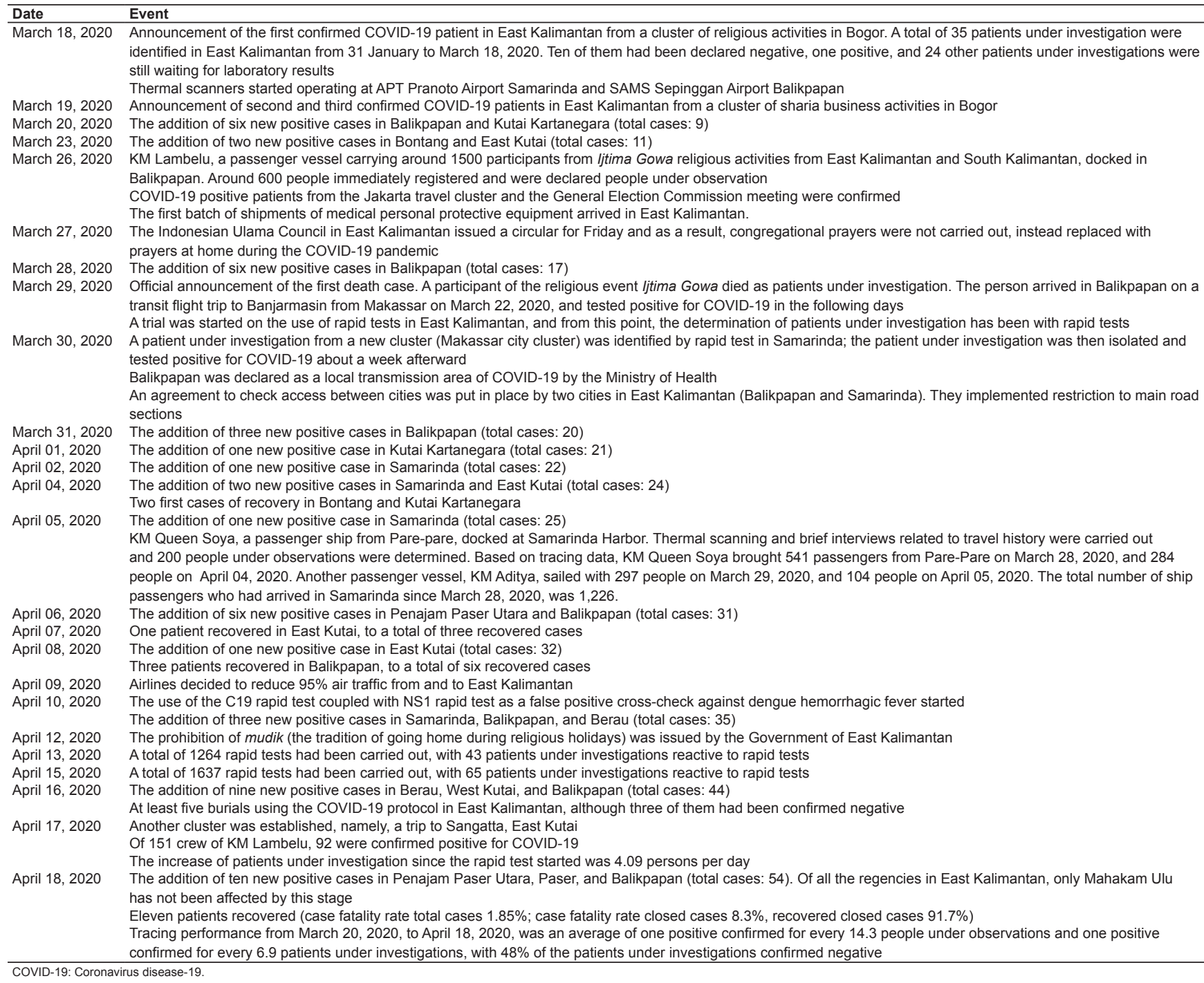

based on contact with positive confirmed COVID-19 or travel to areas that had been designated as local transmission and/or the patient had shown symptoms consistent with COVID-19. The main symptoms are fever $\left(\geq 38^{\circ} \mathrm{C}\right)$ accompanied by dry cough, shortness of breath, body weakness, or diarrhea. As of March 30, 2020, 169 PUls had been established, 84 of which were declared negative and 17 confirmed positive, with 68 PUls waiting for confirmation of test results.

Confirmed COVID-19 patients were isolated in a hospital in the nearest city. Patients with a history of contact or travel to areas with local transmission of COVID-19 and show symptoms resembling COVID-19 were isolated. A part from these categories, all PUO and PUI were urged to carry out independent isolation for at least 14 days in their homes [23].

\section{Use of rapid test in determination of PUI}

The use of finger prick antibody-based rapid tests for the determination of the status of a person suspected of having COVID-19 has been carried out in several countries [25]. Several rapid tests have been recommended by health authorities [26]. The accuracy rate of rapid test detection is expected at $70-90 \%$, depending on the sensitivity of the kit produced by each manufacturer. These tests use a blood sample to detect antibodies (lgG and/or $\lg \mathrm{M}$ ) as the host response to COVID-19 infection [27].

On March 26, 2020, the Government of the Republic of Indonesia, through its Pedoman Pencegahan dan Pengendalian COVID-19 $4^{\text {th }}$ revision, established the procedures for establishing the PUI by rapid test [11]. This device was distributed throughout Indonesia, and East Kalimantan was allocated with 2 400 units of rapid tests. This device arrived on March 27, 2020 and was subsequently distributed to all District Health Offices in East Kalimantan. The use of rapid tests in Samarinda City was first recorded on March 29, 2020. The first result of rapid tests was announced on March 30, 2020. After being screened with rapid test, 175 PUIs had been subjected to the more accurate swab tests, of which 35 PUI swabs were waiting for the swab results (Figure 1). There were 120 confirmed negative PUIs and 20 PUls confirmed positive for COVID-19. 
The use of rapid tests since March 30, 2020, helped the tracing team to identify PUIs. For example, on March 30, 2020, of 169 PUls, 84 were negative for COVID-19 and 17 of them were positive using swab test, and positive cases as a percentage of confirmed negatives were $20.2 \%$. On April 18, 2020, from 352 PUls were registered, 170 were negative, and 54 were positive cases. Hence, positive cases as a percentage of confirmed negatives were $31.8 \%$. Therefore, it was concluded that the use of the rapid test had increased the screening capability of the tracing team.

The increase in PUls with the establishment of rapid tests was 4.09 people per day since March 30, 2020 (Figure 1). On April 16, 2020, a rate of 442 rapid tests and 95.13 swabs per 1 million populations was reported. The number of rapid tests performed on a national scale was not available. However, the rate of swab tests for East Kalimantan was considered slightly lower than the national rate of 156.36 swabs per 1 million populations. As of April 18, 2020, there was a cumulative total of 352 PUls, with 128 people waiting for the results of the swab test. About 170 people were negative and 54 people were positive for COVID-19 [13].

As an important note, the use of rapid tests in Indonesia may be accompanied by other rapid tests. Since Indonesia is a country with endemic Dengue hemorrhagic fever (DHF), some positive blood-based rapid test PUls were cross-checked with the NS1 rapid test designed for DHF. The use of cross-checking with NS1 kits has never been reported in publications in subtropical countries because DHF is endemic to tropical countries [28].

\section{Distribution of COVID-19 to regencies in East Kalimantan}

The dynamics of the spread of COVID-19 are still being elucidated, but a Basic Reproduction Number (R0) of 2.2-5.7 has been reported in the literature [1]. Awareness of the rapid spread of COVID19 needs to be improved. Trips between regions or cities with public transport are considered to be the main contagion vector. The focus of attention is preventing an outbreak of cases in areas with limited health facilities such as the communities in distant and remote areas that are abundant in East Kalimantan [29].

The COVID-19 patients were first confirmed in Samarinda city on March 18, 2020 (Figure 2). Within a week, the spread of confirmed COVID-19 patients expanded to five other regencies. Penajam Paser Utara and Berau recorded positive COVID19 patients, comprising $11 \%$ and $3 \%$, respectively, of the total confirmed cases in East Kalimantan on April 10, 2020. The confirmed number of COVID-19 cases increased to 54, of which 11 were declared cured as reported on April 18, 2020. The spread of COVID-19 has also reached areas distant from

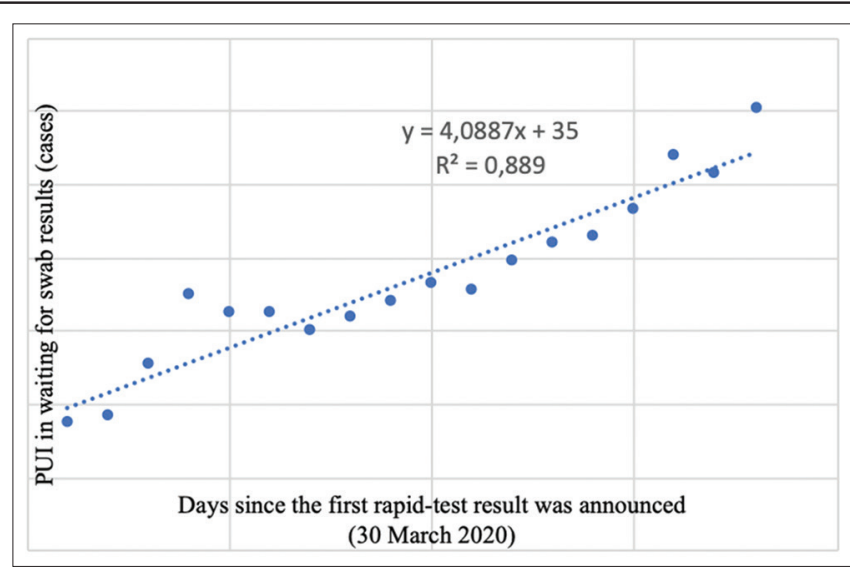

Figure 1: Development of patients under investigation with positive rapid tests since March 30, 2020

airports and main harbors such as the West Kutai and Paser Regency. The highest increase in COVID19 confirmed that patients were in Penajam Paser Utara Regency [13].

\section{Determination of the distribution cluster}

Tracing of the main clusters of COVID-19 distribution was based on a travel history interview or contact by the PUI. COVID-19 patients would confirm their travel history or contact data and were then be submitted to the surveillance teams. After the data were confirmed, the surveillance teams conducted contact tracing based on the information obtained [23]. The main confirmed clusters were subsequently announced in a daily broadcast by the Provincial Health Office. Announcement of the main clusters of the spread of COVID-19 increases community awareness through self-reporting and community reporting through community leaders, heads of villages, and neighborhood units. This is especially important for people without symptoms who have contact with PUI or have a history of travel to areas with local transmission.

\section{Conclusion}

During the month since the first case of East Kalimantan was announced on March 18, 2020, an initial spread of COVID-19 was identified in five regencies and has subsequently reached nine regencies in East Kalimantan. The tracing performance of the 112 teams in East Kalimantan can be considered satisfactory during the 1-month observation period, with a mean of $0.7 \%$ of PUO and $14.4 \%$ of PUI confirmed as COVID-19 positive. The use of rapid tests since March 30, 2020, has increased the detection ability of the tracing team from $20.2 \%$ to $31.8 \%$, expressed as confirmed positive $\mathrm{PUI}$ as a percentage of confirmed negative PUI. The 


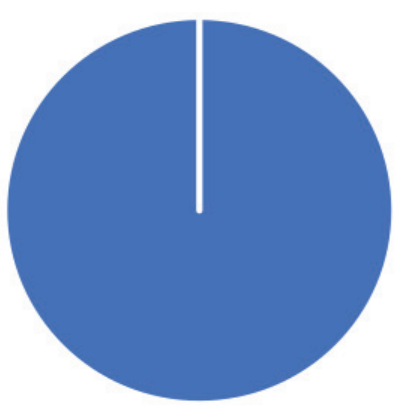

- Sam arinda

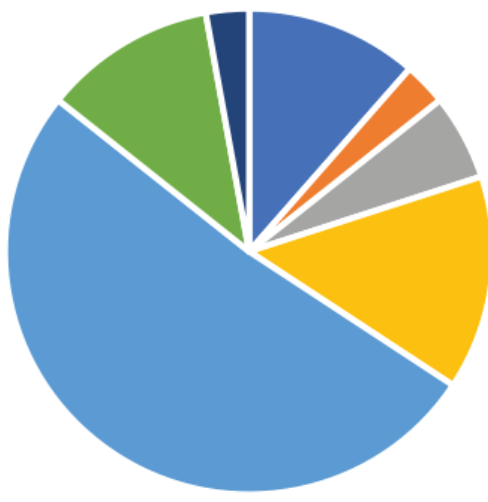

- Kutai Timur

= Bontang

= Kutai Kartanegara

- Sam arinda

- Balikpapan

- Penaja m Paser Utara

- Berau

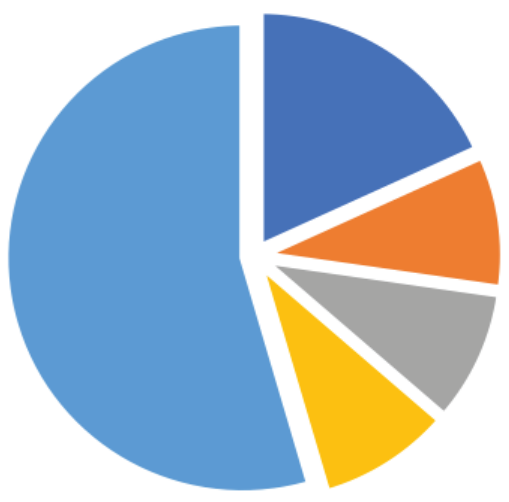

- Kutai Timur

- Bontang

- Kuta i Kartanegara

= Samarinda

- Balikpapan

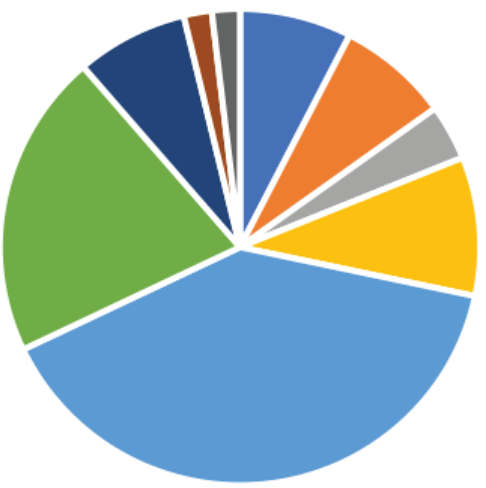

- Kutai Timur

- Bontang

- Kutai Kartanegara

- Sam arinda

- Balikpapan

- Penaja m Paser Utara

- Berau

- Paser

- Kutai Barat

Figure 2: Snapshot of coronavirus disease-19 East Kalimantan cases

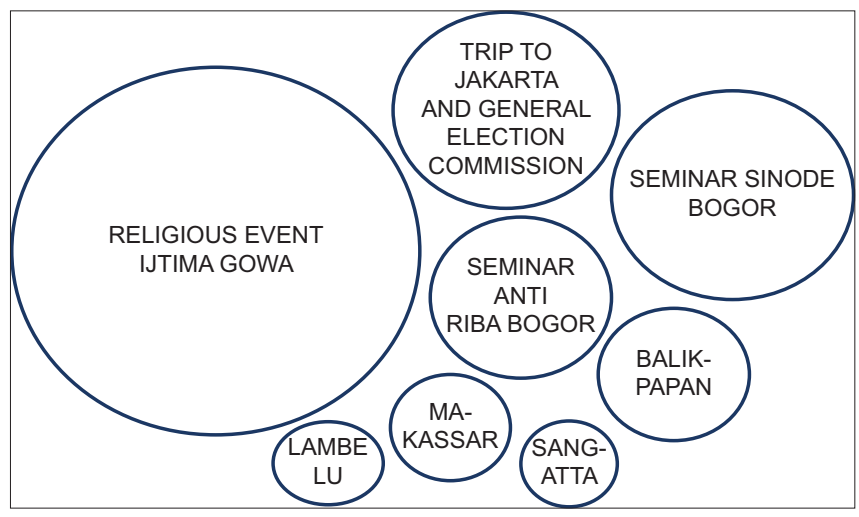

Figure 3: Origin of the East Kalimantan coronavirus disease-19 cluster

use of the COVID-19 rapid test can be cross-checked with a DHF rapid test. Precautions for the spread of COVID-19 should be increased in districts with larger areas and more limited health facilities than in urban areas. Confirmed clusters need to be announced to the public to increase the effectiveness of community selfreporting. In 1 month since the first confirmed patient, 54 cases were confirmed, 11 patients recovered, and one confirmed COVID-19 patient died. The total case fatality rate (CFR) was $1.85 \%$, closed case CFR was $8.3 \%$, while the closed case recovery rate was $91.7 \%$. Tracing of the main clusters of COVID-19 distribution was based on a travel history interview or contact by the PUI (Figure 3). COVID-19 patients would confirm their travel history or contact.

\section{References}

1. Li Q, Guan X, Wu P, Wang X, Zhou L, Tong Y, et al. Early transmission dynamics in Wuhan, China, of novel coronavirusinfected pneumonia. N Engl J Med. 2020;382(13):1199-207. PMid:31995857

2. Baymakova M, Popov GT. COVID-19: A review of part of the international experience. Med Rev. 2020;56(3):5-13.

3. LuR,ZhaoX,LiJ,NiuP,YangB,WuH, etal. Genomiccharacterisation and epidemiology of 2019 novel coronavirus: Implications for virus origins and receptor binding. Lancet. 2020;395(10224):565-74. PMid:32007145

4. Baymakova M, Popov GT. Coronaviruses: SARS-CoV, MERSCoV and SARS-CoV-2 (formerly 2019-nCoV). MD Bulgaria. 2020;17(1):95-102. https://doi.org/10.1002/rmv.2106

5. Gudbjartsson DF, Helgason A, Jonsson H, Magnusson OT, Melsted P, Norddahl GL, et al. Spread of SARS-CoV-2 in the icelandic population. N Engl J Med. 2020;2020:1-14.

6. Gorbiano MI. BREAKING: Jokowi Announces Indonesia's First Two Confirmed COVID-19 Cases. Jakarta, Indonesia: The Jakarta Post; 2020.

7. The Jakarta Post. Indonesia's First COVID-19 Patient Danced with Infected Japanese Woman Before Contracting Virus. Jakarta, Indonesia: The Jakarta Post; 2020.

8. Dipa A. 127 People Linked to Bandung Church Event Test Positive for COVID-19. Jakarta, Indonesia: The Jakarta Post; 2020.

9. Kumparan. Kasus Positif Corona Pertama di Kaltim, Pasien Pernah Ikut Seminar di Bogor. Indonesia: Kumparan; 2020.

10. MauliaE. Jokowi Announces Indonesia's New Capital in East Kalimantan. Tokyo, Japan: Nikkei Asian Review; 2019. 
11. Direktorat Jenderal Pencegahan dan Pengendalian Penyakit. Pedoman Pencegahan dan Pengendalian Coronavirus Disease (COVID-19). Jakarta, Indonesia: Kementerian Kesehatan RI; 2020. https://doi.org/10.31227/osf.io/2ryuv

12. World Health Organization. Clinical Management of Severe Acute Respiratory Infection (SARI) When COVID-19 Disease is Suspected. Geneva, Switzerland: World Health Organization; 2020.

13. Dinas Kesehatan Provinsi Kalimantan Timur. Dinas Kesehatan Provinsi Kalimantan Timur. COVID-19; 2020. Available from: https://www.instagram.com/promkeskaltim. [Last accessed on 2020 Apr 18]. https://doi.org/10.25126/jtiik.201632178

14. Dinas Kesehatan Kota Samarinda. Dinas Kesehatan Kota Samarinda.COVID-19;2020.Availablefrom:https://www.facebook. com/Dinas-Kesehatan-Kota-Samarinda-102415041295389. [Last accessed on 2020 Apr 18]. https://doi.org/10.29103/techsi. v11i1.1134.s328

15. Dinas Kesehatan Kota Balikpapan. Dinas Kesehatan Kota Balikpapan. COVID-19; 2020. Available from: https://www. facebook.com/dkkbppn. [Last accessed on $2020 \mathrm{Apr} 18$ ]. https://doi.org/10.29103/techsi.v11i1.1134.s328

16. World Health Organization. WHO Director-general's Opening Remarks at the Media Briefing on COVID-19-18 March 2020. Geneva, Switzerland: World Health Organization; 2020.

17. Kasulis K. South Korea's Coronavirus Lessons: Quick, Easy Tests; Monitoring. United Kingdom: Al Jazeera; 2020.

18. BBC News. China Coronavirus: Lockdown Measures Rise Across Hubei Province. London, United Kingdom: BBC News; 2020.

19. BBC News. Coronavirus Lockdown in India: Beaten and Abused for Doing my Job. London, United Kingdom: BBC News; 2020.

20. Oktavianti TI. COVID-19: More Regions Request PSBB Status as Indonesia Sees Big Jump in Infections, Deaths. Jakarta, Indonesia: The Jakarta Post; 2020.

21. Nugraha RM, Afifa L. Understanding Indonesia's Coronavirus Acronyms and Terms. Hamburg, Germany: Tempo; 2020.

22. Almerio Y. Awas? Dalam Tiga Pekan ODP di Kaltim Melonjak Menjadi 5.380 Kasus. Indonesia: IDN Times; 2020.

23. Burhan E, Dwi A, Sally A. Protokol Tatalaksana COVID-19. Jakarta, Indonesia: PDPI, PERKI, PAPDI, PERDATIN, IDAI; 2020.

24. Diskominfo Kota Samarinda. Diskominfo Kota Samarinda. COVID-19; 2020. Available from: https://www.facebook.com/ diskominfosamarindakota. [Last accessed on 2020 Apr 18].

25. European Centre for Disease Prevention and Control. An Overview of the Rapid Test Situation for COVID-19 Diagnosis in the EU/EEA. Sweden: European Centre for Disease Prevention and Control; 2020.

26. Purnamasari DM, Gatra S. 3 Rekomendasi Pemerintah Terkait Rapid Test Covid-19. Indonesia: Kompas; 2020.

27. World Health Organization. Advice on the Use of Point-of-care Immunodiagnostic Tests for COVID-19. Geneva, Switzerland: World Health Organization; 2020.

28. Yan G, Lee CK, Lam LT, Yan B, Chua YX, Lim YA, et al. Covert COVID-19 and false-positive dengue serology in Singapore. Lancet Infect Dis. 2020;20(5):536. PMid:32145189

29. Thamrin MY. Carl Alfred Bock, Misi Penjelajahan Etnografi dan Sejarah Alam di Kalimantan. Indonesia: National Geographic Indonesia; 2019. 